\title{
10. Realities, simulacra and the appropriation of Aboriginality in Kakadu's tourism
}

\author{
CHRIS HAYNES
}

\section{Introduction}

Like the previous two chapters, this final chapter is located in the present and recent past. In the sense used by Richard Davis (2005) and other contemporary writers, it imagines colonisation as an extension of the colonial period of the nineteenth and twentieth centuries into the present. It is about some effects of tourism - always a feature of national parks - in Kakadu National Park on Australia's north coast. I argue that tourism generally, especially what is often dubbed 'cultural tourism', has created significant disadvantage for the Aboriginal people of the area. After first introducing this now-famous park, I look at how Kakadu's Aboriginal population is compensated financially, comparing this with the overall value of tourism in the Northern Territory, much of which is generated through marketing representations of Aboriginality. I then look at the complicated mimetic effects arising out of aspects of traditional Aboriginal culture that have been appropriated for touristic advantage in Kakadu. While using quite different data sets and logics, I share anthropologist Lisa Palmer's (2001) earlier conclusion that Aboriginal people have paid a high price in sharing their land with the visitors who enjoy it so much.

\section{Brief history of Kakadu National Park}

Arguably the best known of Australia's national parks, Kakadu is situated in the wet-dry tropics of the Northern Territory of Australia, about $250 \mathrm{~km}$ east of its capital city, Darwin (Figure 10.1). At just less than $20000 \mathrm{sq} \mathrm{km,} \mathrm{comparable}$ in size to small nation-states such as Israel and Belgium, and one-third the size of Australia's smallest state, Tasmania, it is certainly Australia's largest 
national park. Although its administration has nothing like the complexity of nation-states, or even subdivisions of nation-states, it is much more difficult to administer than most national parks, even those of comparable size.

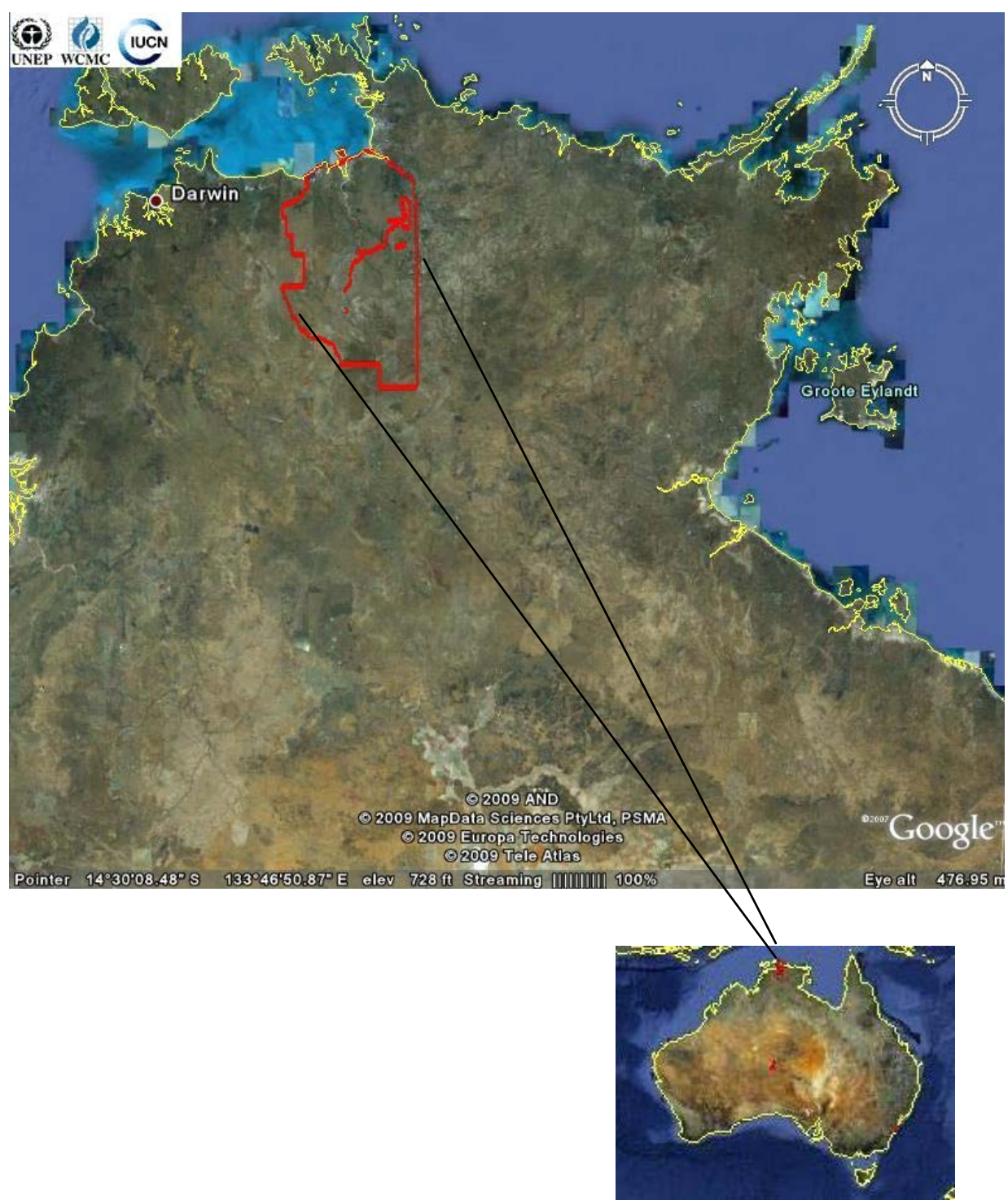

Figure 10.1 Location of Kakadu National Park within Australia. The internal markings denote road, mining and special-purpose excisions

Maps: Google Imagery 2009 and UNEP/WCMC/IUCN 


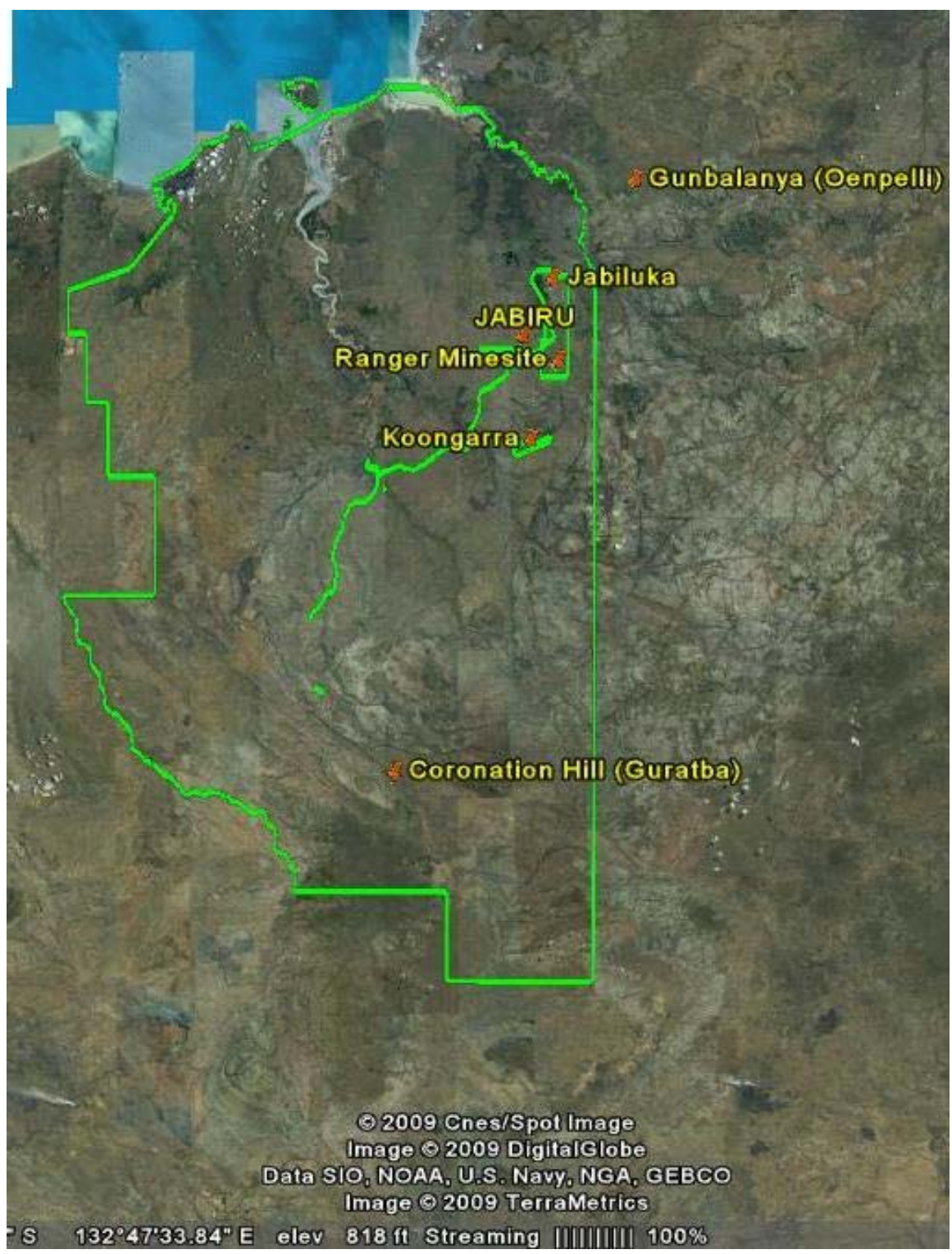

Figure 10.2 Details of boundaries, key features and relevant mining locations within Kakadu. The internal markings denote road, mining and special-purpose excisions. The heavily dissected sandstone sheet that covers western Arnhem Land and extends into Kakadu can be seen extending from the lower right of the image. The park's major river, the South Alligator, lies approximately midway between the eastern and western boundaries. Its catchment is almost completely encompassed within the park boundaries 
Much of its complexity derives from how it was originally devised. The first moves to create a national park in this area took place in the 1960s, as part of a global movement that saw a doubling in number and size of national parks and other protected areas in that decade (Eagles et al. 2002:8; Worboys et al. 2005:41-2). Kakadu was not formally declared until 1979, and then only as the first stage - about one-third of the present area. The delay in its declaration can be attributed to the discovery of significant ore bodies of uranium near the current town of Jabiru (Figure 10.2) and the contestation those discoveries presented. There was not only a potential national park to consider. There were also broader questions of environmental protection and consequences of uranium mining such as nuclear proliferation and the disposal of nuclear waste to be accounted for. Moreover, the Australian Labor Party Government led by Prime Minister Gough Whitlam had initiated the granting of land rights to those Aboriginal people who could demonstrate traditional affiliation to the land as one means of addressing the social disadvantage of this group (Peterson 1982).

Working out how to allow the mining, while at the same time protecting a beautiful landscape that housed an abundance of natural and archaeological treasures, addressing the wider environmental protection questions and doing justice to the traditional owners of the area, provided unprecedented challenges to policymakers. Policy requirements were eventually resolved through two major moves. The first was the appointment of the Ranger Uranium Environmental Inquiry (RUEI 1977), headed by Justice Russell Fox. Over about 20 months, this commission of inquiry heard complex, and often contradictory, evidence on issues ranging from nuclear threats and the disposal of nuclear waste to the intricacies of how Aboriginal land was owned according to local tradition. The second move followed receipt of the RUEI's final report in April 1977 by the federal government. It set up a subcommittee of relevant ministers to work through the considerable detail of the RUEI recommendations with senior public servants, producing a series of detailed decisions several months later (Commonwealth of Australia 1977). Among the most significant of these were: uranium mining was to be permitted, under strict environmental safeguards (including the establishment of a new agency, with its own legislation, that would police the operations of the mine); the first stage of Kakadu National Park would be created; and almost all of that first stage would be granted to Aboriginal land trusts to hold the land on behalf of traditional Aboriginal owners, subject to its being leased to the state to be run as a national park.

After months of controversial negotiations and considerable duress to both traditional owners and state negotiators (see, for example, O'Brien 2003; Parsons 1978; Peterson 1982), the agreements to allow mining at the first-discovered ore body, Ranger, and the lease of about one-third of the current park to the state were signed in November 1978. Construction of the mine site started 
soon afterwards, and the first stage of Kakadu was declared in April 1979. A change in the federal government in 1983 saw other uranium-mining prospects curtailed and an eventual increase in park area to its current size in 1991. The final addition was also controversial, with the possibility of non-uranium mines in the South Alligator Valley (Figure 10.2) remaining until the government decided not to permit mining and to include the whole area in Kakadu.

Although only about half the total area has been successfully claimed on behalf of traditional owners so far, with other claims still to be resolved, the park is now administered as if it were all Aboriginal land and decisions are made jointly by traditional Aboriginal landowners and Parks Australia. The fact that Parks Australia is an agency of the federal government is a matter that has been a source of irritation to successive local NT governments, especially those of conservative persuasion in power between the Northern Territory's self-government in 1978 and 2001 (Heatley 1990:130-2). Between those dates, NT Government ministers pushed hard for Kakadu's administration to be handed over to NT partnership. Later administrations have taken a much softer approach, saying that the matter is up to the traditional owners.

Thus, Kakadu, which, like all national parks, is captive to the tension between conservation of the area's natural resources and current use (cf. Eagles et al. 2002:10-12), is subtended by other big issues as well: mining, Aboriginal land rights and local versus national government control. These bigger issues have periodically captured national and international attention, much of it related to the park's inscription on the list of World Heritage properties - a factor that has made Kakadu all the more politically important (Aplin 2004; Trebeck 2007). Such issues have tended to crowd out consideration of the interplay between the interests of the traditional Aboriginal landowners and public use, notwithstanding the importance of such interplay to the Aborigines, as Palmer (2001) tells us.

In the years of my initial close involvement with Kakadu between 1978 and 1985, tourism was relatively weakly developed, but when I returned as park manager, after an absence of 17 years, between 2002 and 2004, visitor numbers had grown considerably. I was frequently confronted by the strains placed on traditional owners - one factor that in turn imposed on the processes of 'joint management', the sharing management between traditional owners and the state, one of the facets of the agreement that set this park up and which was to be the subject of my doctoral thesis (Haynes 2009). 


\section{Kakadu's value to NT tourism}

Kakadu is variously promoted as a nice, warm place to be in winter; as a spot to catch barramundi and other fish; for its wetlands' other values, such as the abundant birdlife of Yellow Waters; for its scenic open spaces; for the sandstone plateau itself; and the waterfalls and plunge pools, which, notwithstanding difficulties with stray crocodiles in recent years, make ideal swimming holes. Many insiders give much of the credit for Kakadu's popularity to the 1986 film Crocodile Dundee, which showed off many of the best features of the landscape. For a sustained period, visitor numbers increased at a compound rate, exceeding 30 per cent (ANPWS 1989:12). Then a limit to numbers of potential visitors appeared to be reached in the mid-1990s, at about 260000 , followed by a gradual decline to less than 200000 for some years. Numbers have since started to rise again; the park service reported 227000 visitors for 2007-08 (DNP 2008:102).

Aided by the attractions of World Heritage listing and the controversies that have marked its history, Kakadu's landscape alone is probably enough to draw tourists in significant numbers. Yet, as local commentators regularly point out, there are many other fine landscapes, swimming holes and fishing places in the Northern Territory's 'Top End'. In the eyes of many of the same commentators (see, for example, NT News 2006), what makes Kakadu special is its so-called 'Aboriginal culture' - a term appropriated ambiguously into the tourism literature in more recent years. Here writers might mean the tens of thousands of beautiful images painted on overhanging cliffs and other rock surfaces of the sandstone plateau and other archaeological treasures that have been well documented (for example, Chaloupka 1993). Or they might mean to include other diacritics of the traditional culture: painted bodies dancing; men throwing spears; women gathering spike rush or hunting for file snakes; or just people cooking in the traditional way.

Both notions offer the tourist their own encounter with an exotic Other, and a great deal of Kakadu's promotion, and that of the Top End (the section of the Northern Territory lying north of about $15^{\circ} \mathrm{S}$ ), rests on the potential that such an encounter offers. For example, the web site of Tourism Top End, the tourist industry's peak body in Darwin, advertises:

The Top End of the Northern Territory is known for its tropical weather, rich indigenous culture, national parks and laid-back lifestyle. It is home to an eclectic mix of cultures whose outdoor lifestyle is complemented by brilliant sunsets, fantastic fishing and a colourful calendar of outdoor events... 
Kakadu National Park, the largest in Australia, is situated 250 kilometres from Darwin on the Arnhem Highway. Renowned internationally for its natural and cultural wonders, Kakadu has one of the highest concentrated areas of Aboriginal rock art sites in the world. ${ }^{1}$

The skilled wording of such marketing implies a rewarding experience of the world of Aboriginal people - one that could include not only the artefacts of bygone days, but incorporation of a 'rich Indigenous culture' into the visit.

Whether such potential is in fact realised is contested, often emotionally. For example, Kakadu's own surveys over the years suggest that more than 80 per cent of visitors are either 'satisfied' or 'very satisfied' with their visit, and, while only a minority of visitors to the Top End in fact visit Aboriginal art sites (17 per cent), 94 per cent of these visitors were 'very or fairly satisfied' with the experience. Of the even smaller number ( 6 per cent) who participate in Aboriginal guided tours, 100 per cent are 'very or fairly satisfied'. ${ }^{2}$ Almost all such Aboriginal-related activities take place in Kakadu. On the other hand, many white people in Darwin, notably tour operators, consider Kakadu a frustrating entity that delivers only a fraction of its potential to the visitor-a theme that has recurred over the decades of Kakadu's existence as a national park (for example, NT News 1989, 1996a, 1996b; The Weekend Australian 2009). Many whites express exasperation about how traditional owners, aided and abetted by Parks Australia, the current joint-management partner, keep beautiful and interesting areas closed to park visitors. Not only that, they say, most traditional owners refuse to act out the role of 'traditional' Aborigines, in a game many white people claim would certainly enhance Kakadu's unrealised tourism potential.

Contestation and controversy notwithstanding, visitors continue to comeboth to the Top End and to Kakadu. There are several ways of estimating the economic activity they generate. Two of them are considered briefly herethe first based on the aggregate amounts of money spent by tourists in the destination, the method used by Tourism NT, the NT Government's tourism agency. It estimates about 1 million people visit the Top End annually, spending an average of more than $\$ 1000$ each, thus generating just more than $\$ 1$ billion in the Top End economy. ${ }^{3}$ Extending the logic of this method, Kakadu, with its

\footnotetext{
1 Tourism Top End web site, viewed 14 February 2009, <http://www.tourismtopend.com.au/pages/ welcome-to-tourism-top-end/>

2 Destination visitor survey, Tourism NT web site, viewed 14 February 2009, <http://www.tra.australia. com/content/documents/DVS/First \%20Round \%20of\%20Reports/SRR \%20Reports/SRR \%20Darwin \% 20 Final.pdf>

3 Tourism NT web site, viewed 14 February 2009, < http://www.tourismnt.com.au/nt/system/galleries/ download/NTTC_Research/Quick_Stats_YE_Sep08.pdf> All figures are quoted in Australian dollars.
} 
230000 or so visitors, could claim to generate tourist expenditure of about $\$ 230$ million per annum - a share of overall Top End activity that is consistent with economist Pascal Tremblay's (2007:vi) estimate.

Tremblay himself uses a second, more rigorous economic estimation regime, developed by Carlsen and Wood (2004). He argues that its estimates reflect only additional economic activity specifically attributable to the park or region. In other words, the figures discount the fact that tourists would substitute activity in other regions if they did not visit Kakadu or the Top End. By this more conservative methodology, Tremblay estimates the net tourism contribution to the economy by Kakadu is about $\$ 15$ million - about one-quarter of the total Top End net contribution of $\$ 58.1$ million.

\section{Aboriginal people's financial share of tourism}

The most obvious way by which Aboriginal people in Kakadu benefit financially from tourism is through their work in tourism enterprises, both as guides and as informants - work that so many white people insist Aboriginal people should be doing. Some traditional owners and their relatives conduct their own enterprises. Others produce paintings and artefacts that are sold in local retail outlets, but most of those involved in tourism do so as employees in enterprises that are owned by either Aboriginal associations or white people. (Almost all of those actually working in this way are not real traditional owners of Kakadu, but relatives or other people whom traditional owners accept as suitable to be working there.) As well, a few traditional owners have negotiated special deals for tourism to take place in their own areas, and derive a small royalty-style income stream from this source. The annual income from both sources is about $\$ 900$ 000 - a small amount in comparison with what Kakadu generates in the tourism economy, but still considerably larger than it was a few years ago. ${ }^{4}$

There are three other ways through which, I argue, Aboriginal people derive income from tourism in Kakadu. These are channelled through the park organisation itself - the first being the traditional owners' share of visitor use fees, negotiated when these fees were first introduced in 1988. This figure was about $\$ 1.2$ million in $2009 . .^{5}$ Second, traditional owners receive land rent for the park-currently about $\$ 400000$. It could be argued that a proportion of this amount - I suggest half $(\$ 200000)$ - is compensation for the tourists' use

\footnotetext{
4 This is my estimate. In my calculations, I acknowledge the assistance of several private operators and Aboriginal associations, especially Liam Maher of the Djabulugku Association.

5 DNP (2008:101) and Senate, 'Budget Estimates', Hansard, May 2007-answer to Question No. 34 by Senator Crossin (NT). Since its introduction there have been changes to the way in which this payment is made - notably after the abolition of entry fees by the Howard Government in 2004 and their reintroduction by the Rudd Government in 2009.
} 
of the land. ${ }^{6}$ These two sources are shared among about 150 traditional owners. Third, about half of the park's 65 or so employees are Aboriginal, although only a small number of them are in fact traditional owners. These employees earn about $\$ 2.5$ million per annum, of which I estimate about 40 per cent ( $\$ 1$ million) is attributable to providing visitor services, including guided tours that are available during the peak visitor months at no added cost to park visitors. Thus, if one adds these three payments made through Parks Australia (\$2.4 million), Aboriginal income in Kakadu attributable to tourism is about $\$ 3.3$ million per annum.

Although a total of more than three times the direct tourism income, \$3.3 million is still only a fraction of the conservative figures generated by Tremblay $-\$ 58.1$ million for the Top End and \$15 million for Kakadu - especially when one notes the use of Aboriginality to attract visitors to the Top End in general, and Kakadu in particular. Of course, if one makes the comparison with the grand figures of $\$ 1$ billion for the Top End, or $\$ 230$ million for Kakadu, the fraction becomes not modest, but tiny. I suggest this could be one factor that has made it harder to persuade traditional owners to embrace tourism in both Kakadu and the Top End generally. ${ }^{7}$

\section{How Aboriginal 'culture' is commodified in Kakadu}

Commodification of traditional culture and its recognition are hardly new ideas. As Sahlins (1999:401) notes: All of a sudden, everyone got "culture". Australian Aboriginals, Inuit, Easter Islanders...even peoples whose ways of life were left for dead or dying a few decades ago now demand an indigenous space in a modernizing world under the banner of their "culture".' In the sense that Sahlins is describing, it is the subject peoples themselves who are enacting such commodification. Traditional owners and other Aboriginal people in Kakadu do exactly this, showing off so much of 'traditional culture' as suits their purposes, such as to argue identity and the protection of Aboriginal rights, as they do in Kakadu's management plans (for example, KNP and DNP 2007:45), and to earn income through showing tourists an exotic Otherness.

\footnotetext{
6 Tourism is not the only inconvenience attributable to the park that traditional owners have to manage. For example, there are conservation projects such as feral animal control (Bradshaw et al. 2007; Robinson et al. 2005) that create conflict between them and the park service.

7 Some commentators (for example, Tremblay 2008:73-5) point out that an opposite case can be made - that is, that if Aboriginal people had been more enthusiastic in taking up tourism opportunities they would now be much bigger players in tourism, and hence beneficiaries of it. Notwithstanding this argument, while I was park manager, I heard many complaints from Kakadu traditional owners that they were not gaining the benefits from tourism that the many white people in Darwin were receiving.
} 
But what of the gap that appears to open up when one considers another view of culture? By 'culture' here I mean neither Kakadu's archaeological treasures such as the thousands of rock paintings nor the commodified re-enactments such as dancing, hunting and cooking, but rather the Geertzian (1993:5) view: 'The concept of culture I espouse...is essentially a semiotic one. Believing, with Max Weber, that man is an animal suspended in webs of significance he himself has spun, I take culture to be those webs.' If we take such a view then the webs of significance that 'suspend' traditional owners today are, in many respects, quite different from those that suspended the traditional owners of 30 years ago when the park got under way, and radically different from those that suspended their forebears encountered by explorer Ludwig Leichhardt when he descended from Kakadu's sandstone plateau in 1845. We have some clues about how culture changed through the colonial period: about how the whole population almost died out (Keen 1980:34-44), how migration patterns and fire regimes changed (Brockwell et al. 2001), how the remaining traditional owners migrated back and forth to towns and stations, with many eventually settling into casual work for white buffalo shooters, and how they demonstrated an early version of what Altman (2005), for example, calls the hybrid economy, purchasing Western goods while continuing to 'live off the land' much as their ancestors had done, thus engaging in different modes of production.

We know much more about changes that have taken place in the past three decades. In this period, we have seen most of the senior traditional owners die and be replaced as authority figures by people who have received at least some schooling and who do not remember much about the area before the park existed. We have seen rapid, but under-scrutinised changes in technology and infrastructure: the creation of the town of Jabiru, with its shops and other amenities; construction of sealed roads that have cut travel times by two-thirds; the building of modern tourist facilities, district offices and housing for staff throughout the park; and the introduction of phones and internet connections into all park offices - just to name a few.

All these technologies, let alone more complex things such as the intrusion of the state into their daily lives, and the ways by which traditional owners and other Aboriginal people have responded to them, make for transformed webs of significance to contemporary traditional owners. Many of the park's Aboriginal people - those who tend to play the most active roles in the park-now live in the same kind of housing, shop in the same shops and own the same kinds 
of cars and boats as their white counterparts. ${ }^{8}$ Thus, although they continue to have responsibility for, and frequently worry about, their traditional clan estates, these days their firsthand knowledge of 'country' is generated largely through their employment or recreational visits to it in their 'spare time'. Likewise, much of their knowledge of what is told to, or performed for, park visitors is gained with the help of Western technologies such as video and audio recordings. Yet, like Sahlins (1999:409) in his critique of the meaning of Sumo, I argue that the narratives and performances for the tourists are much more than mere diacritics of long-gone cultures; no matter how they are learned and reproduced, they are the work of Aboriginal people themselves and, in this sense, they are 'authentic'.

Other people and agencies commodify Aboriginal culture too. In this sense, I see commodification as appropriation. I have already mentioned the skilled word images of tourism promoters on web sites. Such messages are reproduced, often pictorially as well, in other media, and they continue to be reproduced verbally by the many white tour guides that traverse the park throughout the year as they sell their own versions of the 'authentic' Aboriginal people. In the park's early days, some of the guides enthralled visitors with stories about, for example, 'tribal' murders, 'pay-back' killings and bizarre sexual behaviour. Park service activities such as judicious 'listening in' to tour guides, and its education programs, as well as self-policing by tour operators themselves, have truncated the more outrageous misinformation perpetrated by guides. Misinformation persists, however, and probably always will, as will all kinds of representations of Aboriginal people by whites.

It is relatively easy to identify the strange, even bizarre, appropriations of Aboriginal culture by commercial tour guides. More difficult to classify are the various appropriations by the park service itself. It is on these that I now wish to focus. Done with the complicity of traditional owners themselves, always first created with their explicit permission, these simulacra of past cultures, I argue, expose the tensions that lie between them and the culture of now.

\section{The seasonal calendar and burning off}

The brochure that has been handed by park employees to hundreds of thousands of visitors provides considerable information about visitor safety

8 Some residents, especially those who are neither traditional owners nor park employees, are not so well off materially. Yet, through the strength of various affiliations with traditional owners, these people are able to continue residence in Kakadu. While they take advantage of access to fishing and hunting, in accordance with the agreement, and therefore live a more 'traditional' life than their more affluent counterparts, their lives have been changed too. For example, most have access to transport, shopping, health services and other forms of social security. 
and general information about the park and suggests activities for visitors. This includes information about aspects of Aboriginal culture-here a tripwire to some awkwardness that can arise when representing and appropriating other cultures.

The text (Environment Australia 2003:11) explains how the collapse of original populations disrupted what are thought to have been traditional fire regimes, relying as they did on many small fires that went out during the night in the cooler months (see, for example, Levitus 2005). Backed by Western science (for example, Edwards et al. 2003; Russell-Smith et al. 1998), park managers try to simulate these, mainly by dropping from helicopters permanganate-filled ping-pong balls injected with glycol. These little balls ignite on reaching the ground and theoretically take the place of the former hunter-gatherers and their fire-sticks. Done in the name of good land management, it is called 'planned burning', but it is not the same as what the region's people call anwurrk, in which burning off the vegetation is part of being, caring for one's own land and thereby expressing ownership of it (Verran 2002).

The brochure does not explain that 'planned burning' is a metonym of imagined tradition - the practice of which now largely excludes the very people whose ancestors once did it all and in different ways. Unable to argue against the logic, backed by Western science, that white managers are simulating 'Aboriginal burning practices' for the good of the country, traditional owners and the other Aboriginal people have the choice to either comply with these mimetic fire regimes or rebel-lighting fires in the hot periods of the year during which fires spread rapidly and can burn for weeks on end. So, while Sherry Ortner (1984:154) famously notes that 'hegemony is always more fragile than it appears', in Kakadu we see the fire program dominated by whites in the name of 'authentic Aboriginal culture' (and Western science too) and only sporadic frustrated resistance by traditional owners and their countrymen and women.

The Gundjeihmi seasonal calendar (Figure 10.3) is also reproduced in the brochure (Environment Australia 2003:10). This was in fact the product of an afternoon's work in December 1978 (and a few hours of later checking) by then traditional owners Toby Gangali and Mick Alderson, with me asking questions and acting as scribe. (Note that the original spellings have been retained in Figure 10.3.) At the time, Mick was quizzical: 'Why would whitefellas want to know about all this?' My response-'So that they know how blackfellas are smart' - bemused but still satisfied him, as it seems to have satisfied many traditional owners since then. Yet this form of appropriation, this mimetic transformation of an abstracted traditional knowledge on to paper, constitutes a double imposition on Aboriginal people. 


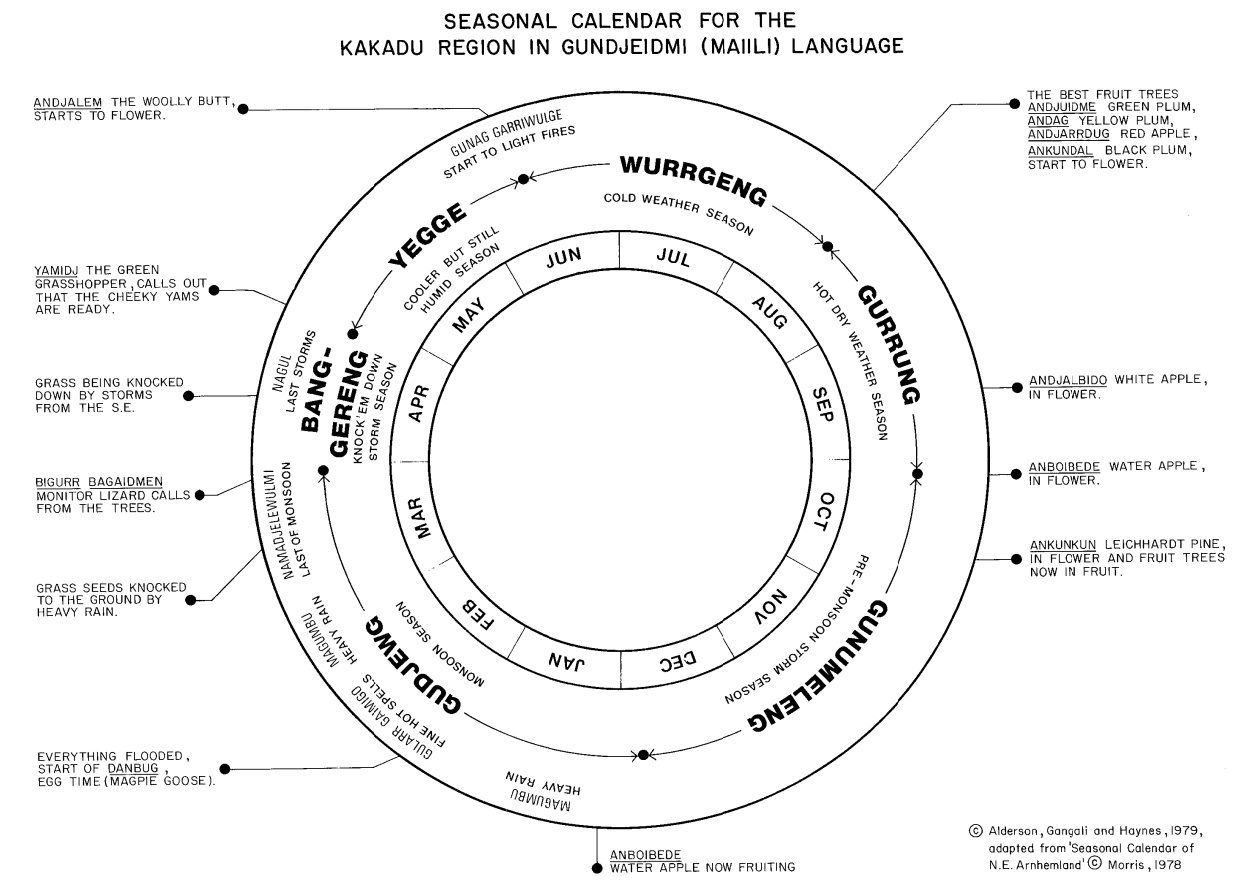

\section{Figure 10.3 Seasonal calendar for the Kakadu region in the Gundjeihmi (Maiali) language}

First, its very documentation (and subsequent re-presentation in almost uncountable numbers of books, in the park brochures that have been handed out to literally millions of people, on stone tablets at the park's visitor centres, and even on T-shirts) means that for white people it is privileged as a way of knowing, in recognisable iconography. It can be used, and is used, as a means of telling Aboriginal people what their 'authentic' culture is -implying that they themselves are in-authentic. For while the park service and its individual white actors do recognise that Aboriginal lives are not the same after three decades of mining, the park and all those visitors, they tend to frame that recognition in the manner of the structural-functionalist anthropologists who periodically talked about the collapse of former cultures (for example, Berndt and Berndt 1988:492).

This leads into the second imposition on Aboriginal people - part of mimesis itself. The images here are the representations of the seasonal calendar and how the state both practises and represents planned burning that is based on anwurrk-but is not anwurrk. As the person who enthusiastically documented the seasonal calendar in the first place, and one of those who (also enthusiastically) persuaded the park service to imitate Aboriginal fire regimes (Haynes 1985), 
I work through the following argument as a cautionary tale as much, if not more so, against myself as against the park service or other white people who have worked there.

Considering Sir James Frazer's (1890) musings about imitation, Michael Taussig (1993:65) notes: 'How much more complex than Frazer's "like affecting like" this magical power of the image becomes! This power intrinsic to mimesis and alterity on the frontier is as much a destructive as a healing force.' As I thought at the time (like Frazer), what could have been more assuring and flattering to traditional owners than imitation? When I responded to Mick Alderson's question about why whitefellas would want to know all this with 'so that they know how blackfellas are smart', I meant it as one means of healing: as a means of rapprochement with traditional owners; as a means of driving into the background the overt and vicious racism that was abroad three decades ago when the park was declared; and as a means of convincing park visitors that Aboriginality meant not just the antiquity of the rock paintings but the culture of a clever people. I had no idea then that simple things such as the introduction of roads, park radio and phones, and the more complex phenomena such as the intrusion of the state into their daily lives, as well as their responses to all this and more, would transform culture and open the way for the destructive forces that lie within mimesis to appear.

In another theoretical view of mimesis - one that lays bare the double-sided and corrupting nature of imitation-Homi Bhabha (1994:91) notes:

Under cover of camouflage, mimicry, like a fetish, is a part object that radically revalues the normative knowledges of the priority of race, writing, history. For the fetish mimes the forms of authority at the point at which it deauthorises them. Similarly, mimicry rearticulates presence in terms of its 'otherness' that which it disavows.

The park service's imitation of the seasonal calendar (while transforming it into an alien, written object) and its imitation of as much of traditional fire regimes as suits 'good conservation', rearticulates traditional forms of authority and simultaneously de-authorises their value to traditional owners. Bhabha (1994:88) points out elsewhere that mimesis involves metonymy-taking part of the whole to represent the whole. In so doing, here it not only de-authorises the value of these traditional forms of authority, it de-authorises the traditional owners themselves as well.

The argument here is that while traditional owners are generally pleased to have had their traditions and customs recognised, that same recognition can, and does, cause them grief too. The challenge to their authenticity is always there, 
whether it is being actively discussed or not. As Francesca Merlan (1998:150) notes: 'Representations of Aboriginality as made most powerfully by others come to affect who and what Aborigines consider themselves to be.'

\section{Exploring the future}

The appropriation of Kakadu's Aboriginality has been manifestly beneficial to the tourism industry of the Top End. I have argued that such appropriation has not yielded particularly good results for the Aboriginal people themselves. First, although one can endlessly dispute which sets of figures should be used for comparison, the Aboriginal share of the tourism economy is small. Second, they have partially given up, or had taken from them, in various forms, their capacity to represent their own culture.

While discussing the agency of web sites, government organisations and tour guides, I admitted that representations of Aboriginality, even powerful representations, are one part of the future. One consequence, then, is that, as Merlan says, Kakadu's traditional owners will continue to think of themselves as, in part, within the referential framings of white Others. The question here is how Aboriginal agency might be demonstrated within the fields of power that have been so clearly established. And there are two sub-questions: how might Aboriginal people take a larger share of the tourism cake; and how might they take back some of the ways by which they might represent themselves?

I suggest that possible answers to both sub-questions could already be demonstrated in response to an initiative of a previous federal government of Prime Minister John Howard. Early in 2006, Parliamentary Secretary for the Environment, Greg Hunt, launched a new program that had followed about a year of consultation between the government and the Kakadu Board of Management. My fieldwork was at the periphery of it, and nothing I heard from my participants made me inclined to take much notice of this initiative, which was supposed to encourage Aboriginal people to build on their small existing involvement by establishing their own enterprises and, in particular, building links with the tourism industry. Inured by three decades of watching Aboriginal reticence about becoming seriously involved in tour guiding, it was hard for me to view the program as anything other than yet more bullying of traditional owners by the state, in order to expand tourism and create more jobs for Darwin-based whites.

The number, robustness and value of Aboriginal tourism enterprises have increased, however - albeit from a tiny base. I estimate that the current income gained by Aboriginal people - $\$ 900000$ - represents an increase of about 50 
per cent over the amount generated in 2006. ${ }^{9}$ Although the potential to grow this income is limited, both by the numbers of Aboriginal people available to do the work and by what the tourist market is prepared to pay for cultural tours, Aboriginal participation is increasing. On interviewing several newcomers recently, journalist Fiona Carruthers (2009) noted: 'The signs of change are everywhere.' The new Aboriginal participants also appear to be realistically enthusiastic about their prospects, as former park ranger and now partner in a small tour operation Fred Hunter noted on television in August 2008:

You know, working with parks for quite a number of years I never saw hardly any Indigenous guides, hardly at all...and in just the last couple of years, just seeing the different companies starting up, it's been really good and there needs to be more of it, especially people from this country talking about their country and about their culture. (7.30 Report, ABC Television, 28 August 2008)

There is, as well, potential to increase the passive incomes through royalty-style payments such as shares of park fees and access into special places that require supervision. After all, as I have shown, the real Aboriginal share of tourism is paltry.

Perhaps the real dollar increases are less important than traditional owners and other Aboriginal people reappropriating ways in which their culture is represented, as a means of decoupling themselves from the mimesis in which they have become unwittingly involved. Tour guiding is not the work that most Aboriginal people prefer. Yet if tourism is more firmly controlled by Aboriginal people themselves, it will be they who have much greater control over what visitors should know, recovering past injustice and allowing the uncomplication of the complicated. In saying this, I am agreeing with Lisa Palmer's (2001:267) conclusion:

The key to imagining Kakadu as an Aboriginal place lies in the relationship people construct with each other through their relations with the landscape. If the landscape is viewed as a living subject where relationships to the land and to each other continue to change with time, a new construction of Kakadu can emerge.

Palmer's emphasis here is on reconstruction of how people interact with land, but important keys also are the possibilities that are allowed through each changing with time, in particular in ways that allow Aboriginal people to retake ground that has been lost in the rush to represent their culture.

9 I estimate that between 2006 and 2008, the number of Aboriginal individuals involved in tourism (including artists) has increased from about 60 to 90 , and income has increased from $\$ 590000$ to more than $\$ 900000$. 
The emphasis of this chapter has been directed towards some ways in which Aboriginal people have participated in the economies of the market and the state. This is not to deny that other economies (those based on traditional exchange, mutual obligation and demand sharing, for example) are at work, as they still are in Kakadu. For in many ways Kakadu's Aboriginal people still transact business in ways similar to those described by Lorraine Gibson in Chapter 8: maintenance of family relations is often privileged over work as it is defined by the market economy. My purpose has been not to deny the richness and complexity of the hybridity of the economies here, but rather to demonstrate how Aboriginal participation in what Noel Pearson (2000, 2001) calls the 'real world' has in fact resisted the welfare colonialism articulated by Robert Paine (1977). Indeed, rather than a situation in which value as defined by Western thinking is flowing from the centre to the periphery, I suggest that Aboriginal people are being short-changed in their contributions to the tourism of Australia's north.

\section{Acknowledgments}

I gratefully acknowledge Liam Maher's considerable assistance in the compilation of the tourism value estimates. Jon Altman, Tess Lea, Lisa Palmer and Pascal Tremblay provided valuable comments on earlier drafts of this chapter.

\section{References}

Altman, J. 2005, 'Economic futures on Aboriginal land in remote and very remote Australia: hybrid economies and joint ventures', in D. Austin-Broos and G. Macdonald (eds), Culture, Economy and Governance in Aboriginal Australia, Sydney University Press, NSW, pp. 121-33.

Aplin, G. 2004, 'Kakadu National Park World Heritage site: deconstructing the debate, 1997-2003', Australian Geographical Studies, vol. 42, pp. 152-74.

Australian National Parks and Wildlife Service (ANPWS) 1989, Australian National Parks and Wildlife Service. Annual Report 1988-89, Australian Government Publishing Service, Canberra.

Berndt, R. M. and Berndt, C. H. 1988, The World of the First Australians, (Fifth edition), Aboriginal Studies Press, Canberra.

Bhabha, H. K. 1994, The Location of Culture, Routledge, London and New York. 
Bradshaw, C. J. A., Field, I. C., Bowman, D. M. J. S., Haynes, C. and Brook, B. 2007, 'Current and future threats from non-indigenous animal species in northern Australia: a spotlight on World Heritage Area Kakadu National Park', Wildlife Research, vol. 34, pp. 419-36.

Brockwell, S., Clarke, A. and Levitus, R. 2001, 'Seasonal movement in the prehistoric human ecology of the Alligator Rivers region, North Australia', in A. Anderson, I. Lilley and S. O'Connor (eds), Histories of Old Ages: Essays in honour of Rhys Jones, Pandanus Books, Canberra, pp. 361-80.

Carlsen, J. and Wood, D. 2004, Assessment of the Economic Value of Recreation and Tourism in Western Australia's National Parks, Marine Parks, and Forests, Cooperative Research Centre for Sustainable Tourism, Gold Coast, Qld.

Carruthers, F. 2009, 'Walkabout on the wild side', Australian Financial Review [weekend edition], 29-31 May 2009, pp. L10-11.

Chaloupka, G. 1993, Journey in Time, Reed, Chatswood, NSW.

Commonwealth of Australia 1977, Uranium: Australia's decision, Australian Government Publishing Service, Canberra.

Davis, R. 2005, 'Introduction: transforming the frontier in contemporary Australia', in D. B. Rose and R. Davis (eds), Dislocating the Frontier: Essaying the mystique of the outback, ANU E Press, Canberra, pp. 7-19.

Director of National Parks (DNP) 2008, Director of National Parks. Annual report 2007-08, Australian Government, Canberra.

Eagles, P. F., McCool, S. F. and Haynes, C. D. 2002, Sustainable Tourism in Protected Areas: Guidelines for planning and management (best practice protected areas guidelines), IUCN, UNEP and WTO, Gland, Switzerland, and Cambridge.

Edwards, A., Kennett, R., Price, O., Russell-Smith, J., Spiers, G. and Woinarski, J. 2003, 'Monitoring the impacts of fire regimes on vegetation in northern Australia: an example from Kakadu National Park', International Journal of Wildland Fire, vol. 12, pp. 427-40.

Environment Australia 2003, Kakadu National Park: Visitor guide and maps, Commonwealth of Australia, Darwin.

Frazer, J. G. 1890, The Golden Bough: A study in magic and religion, Macmillan, London.

Geertz, C. 1993, The Interpretation of Cultures, Fontana Press, London. 
Haynes, C. 1985, 'The pattern and ecology of munwag: traditional Aboriginal fire regimes in north central Arnhemland', Proceedings of the Ecological Society of Australia, vol. 13, pp. 203-14.

Haynes, C. 2009, Defined by contradiction: the social construction of joint management in Kakadu National Park, Unpublished PhD thesis, Charles Darwin University, Darwin.

Heatley, A. 1990, Almost Australians: The politics of Northern Territory selfgovernment, North Australian Research Unit, The Australian National University, Darwin.

Kakadu National Park and Director of National Parks (KNP and DNP) 2007, Kakadu Board of Management and Director of National Parks. Kakadu National Park. Management plan 2007-2014, Australian Government, Darwin.

Keen, I. 1980, 'The Alligator Rivers Aborigines: retrospect and prospect', in R. Jones (ed.), Northern Australia: Options and implications, Research School of Pacific Studies, The Australian National University, Canberra, pp. 171-86.

Levitus, R. 2005, 'Management and the model: burning Kakadu', in M. Minnegal (ed.), Sustainable environments, sustainable communities: potential dialogues between anthropologists, scientists and managers, SAGES Research Paper No. 21, University of Melbourne, Vic., pp. 29-35.

Merlan, F. 1998, Caging the Rainbow: Places, politics and Aborigines in a north Australian town, University of Hawai'i Press, Honolulu.

NT News 1989, 'Buffalo slaughter "hurting tourism"', Northern Territory News, 4 November 1989 , p. 3.

NT News 1996a, 'Kakadu war: tour guides blast feds', Northern Territory News, 13 March 1996, p. 6.

NT News 1996b, 'Park poser 21 years on', Editorial, Northern Territory News, 13 March 1996, p. 10.

NT News 2006, '(Kakadu) (Kakadon't) Kakatrue', Northern Territory News, 18 March 2006, pp. 16-17.

O'Brien, J. 2003, 'Canberra yellowcake: the politics of uranium and how Aboriginal land rights failed the Mirarr people', Journal of Northern Territory History, vol. 14, pp. 79-91.

Ortner, S. B. 1984, 'Theory in anthropology since the Sixties', Comparative Studies in Society and History, vol. 26, pp. 126-66. 
Indigenous Participation in Australian Economies

Paine, R. 1977, 'The path to welfare colonialism', in R. Paine (ed.), The White Arctic: Anthropological essays on tutelage and ethnicity, Memorial University of Newfoundland, St John, pp. 3-28.

Palmer, L. 2001, Kakadu as an Aboriginal place: tourism and the construction of Kakadu National Park, Unpublished PhD thesis, Northern Territory University, Darwin.

Parsons, D. 1978, 'Inside the Ranger negotiations', Arena, vol. 51, pp. 134-43.

Pearson, N. 2000, Our Right to Take Responsibility, Noel Pearson \& Associates, Cairns, Qld.

Pearson, N. 2001, On the human right to misery, mass incarceration and early death, The Dr Charles Perkins Memorial Oration at the University of Sydney, Cairns, Qld, 25 October 2001.

Peterson, N. 1982, 'Aboriginal land rights in the Northern Territory of Australia', in E. B. Leacock and R. B. Lee (eds), Politics and History in Band Societies, Cambridge University Press, UK and Paris, pp. 441-62.

Robinson, C. J., Smyth, D. and Whitehead, P. J. 2005, 'Bush tucker, bush pets, and bush threats: cooperative management of feral animals in Australia's Kakadu National Park', Conservation Biology, vol. 19, pp. 1385-91.

Ranger Uranium Environmental Inquiry (RUEI) 1977, Ranger Uranium Environmental Inquiry: Second report, Australian Government Publishing Service, Canberra.

Russell-Smith, J., Ryan, P. G., Klessa, D., Waight, G. and Harwood, R. 1998, 'Fire regimes, fire-sensitive vegetation and fire management of the sandstone Arnhem Plateau', Journal of Applied Ecology, vol. 35, pp. 829-46.

Sahlins, M. 1999, 'Two or three things that I know about culture', Journal of the Royal Anthropological Institute, (NS) vol. 5, pp. 399-421.

Taussig, M. 1993, Mimesis and Alterity: A particular history of the senses, Routledge, New York.

The Weekend Australian 2009, 'Tarnished treasure: Kakadu becomes Kakadon't', The Weekend Australian, 17 January 2009, p. 1.

Trebeck, K. A. 2007, 'Tools for the disempowered? Indigenous leverage over mining companies', Australian Journal of Political Science, vol. 42, pp. 54162. 
Tremblay, P. 2007, Economic Contribution of Kakadu National Park to Tourism in the Northern Territory, Cooperative Research Centre for Sustainable Tourism, Darwin.

Tremblay, P. 2008, 'Protected areas and development in arid Australiachallenges to regional tourism', The Rangeland Journal, vol. 30, pp. 67-75.

Verran, H. 2002, 'A postcolonial moment in science studies: alternative firing regimes of environmental scientists and Aboriginal landowners', Social Studies of Science, vol. 32, pp. 1-34.

Worboys, G. L., Lockwood, M. and de Lacy, T. 2005, Protected Area Management: Principles and practice, (Second edition), Oxford University Press, South Melbourne. 